\title{
Application of Clove Leaf Oil (Syzygium aromaticum L.) on Preservation of Milkfish (Chanos chanos)
}

\author{
*Rukmawati, Daud K. Walanda \& Irwan Said \\ Program Studi Pendidikan Kimia/FKIP - Universitas Tadulako, Palu - Indonesia 94119 \\ Received 09 March 2021, Revised 13 April 2021, Accepted 05 November 2021 \\ doi: 10.22487/j24775185.2021.v10.i4.pp218-223
}

\begin{abstract}
Clove leaf oil (Syzygium aromaticum L.) is obtained from distilling clove leaves. This study aimed to examine the effect of clove leaf oil on the preservation of milkfish meat. Clove leaf oil was obtained by steam distillation and purified by a simple distillation method. The number of microbes was determined using the total plate count (TPC) method, while the organoleptic test used a level of preference for color, smell, texture, and taste. The results showed that the $p H$ and the number of fish meat bacteria at a concentration of $8 \%$, when left for one day, were 6.61 and $2.46 \times 10^{-7} \mathrm{CFU} / \mathrm{mL}$, while the three days was 7.2 and $2.98 \times 10^{-7} \mathrm{CFU} / \mathrm{mL}$, a concentration of $10 \%$ in 1 day which was 6.64 and $2.03 \times 10^{-7}$ CFU/mL while the three days was 7.25 and $2.54 \times 10^{-7} \mathrm{CFU} / \mathrm{mL}$ and a concentration of $12 \%$ in 1 day was 6.67 and $1.83 \times 10^{-7} \mathrm{CFU} / \mathrm{mL}$ while three days was 7.57 and $2.07 \times 10^{-7} \mathrm{CFU} / \mathrm{mL}$, besides that from organoleptic test data the panelist preference rate was more significant in the concentration of $12 \%$ then the concentration of 10 and $8 \%$, respectively. The results showed that at a concentration of $12 \%$, it was a good concentration to be used as preservation compared to a concentration of $10 \%$ and a concentration of $8 \%$, both for a 1-day and a 3-days. This shows that the higher the concentration of clove leaf oil, the greater the ability to preserve fish meat.
\end{abstract}

Keywords: Clove leaf oil (Syzygium aromaticum L.), preservation, milkfish meat

\section{Introduction}

Donggala Regency is one of the cloveproducing areas in Central Sulawesi, with total production in 2011 amounting to 7,995 tons. In 2011, Donggala Regency was the second-largest clove producer in Central Sulawesi after Toli-toli. The total area of clove plants in Donggala district is 3880 ha, with a total production of 1445 tonnes and a productivity of 0.37 tonnes/ha; farmers in managing their farming use this. Sojol District is a sub-district in Donggala Regency, a clove plantation. The land area contained in the Sojol sub-district in 2011 was placed at 2,574 ha (Gusmawati et al., 2014).

Cloves belong to the Myrtaceae family, widely grown in several countries, including Indonesia. This plant is used as an essential oil producer. Clove oil can be obtained from clove oil, clove steam oil, and clove leaf oil. The actual oil content in clove flowers reaches $21.3 \%$ with eugenol levels between $78-95 \%$, from the flower stalks or peduncles up to $6 \%$ with eugenol levels between $89-95 \%$, and clove leaves reaching $2-3 \%$ with eugenol levels between 80-85\% (Hadi, 2012).

Essential oil is a type of vegetable oil that has many benefits. Its physical characteristics are viscous liquids that can be stored at room temperature. One of the main characteristics of essential oils is that they are volatile and have a distinctive aroma. Therefore, this oil is widely used as a base for making fragrances and cosmetics (Kataren, 1990). Based on the research results at the Research Institute for Spices and Medicines, clove products in the form of leaves, stalks, flowers, clove oil can suppress and even kill the growth of fungal mycelium, bacterial colonies, and nematodes. Therefore, clove products can be used as fungicides, bactericides, nematicides, and insecticides (Nurdjannah, 2004). In addition, clove oil contains eugenol, which has eugenol activity as an antimicrobial in the preservation process (Towaha, 2012). Therefore, vegetable antioxidants such as eugenol in food products are a safe alternative for health, such as in foods containing fat or oil, including cooking oil, cheese, margarine, tomato sauce, bread, and processed meats and cereals. In addition, the antioxidant eugenol and its derivatives are also commonly used in cosmetic and medicinal products and the plastic and rubber industries (Sharma et al., 2006).

Preservation is an essential aspect of extending the shelf life of a food product. Especially for products with a short shelf-life, the benefit of

*Correspondence:

Rukmawati

e-mail: rukmawati025@gmail.com

(c) 2021 the Author(s) retain the copyright of this article. This article is published under the terms of the Creative Commons Attribution-NonCommercial-ShareAlike 4.0 International, which permits unrestricted non-commercial use, distribution, and reproduction in any medium, provided the original work is properly cited. 
preservation is that it can reduce the metabolic rate or even delay the metabolism of microorganisms that can affect a food product, for example, spoilage. One foodstuff that is susceptible to spoilage is fish because fish is easily damaged after being caught and after death and is easily contaminated by microbes. The microbial contamination causes damage and deterioration of quality in fish. However, many people consume fish because of its high nutritional value (Andayani et al., 2014). So far, the community's preservation process to make the fish last longer is cooling and smoking/drying.

Apart from this process, the addition of substances can also help to preserve fish. These additives can be natural substances or artificial substances, and usually, what is often used are sugar and salt. Based on the regulation of the Minister of Health No. 033 of 2012 concerning food additives, substances that can be used to preserve food include salt $(\mathrm{NaCl})$, ascorbic acid, potassium ascorbate, sodium nitrate, and potassium nitrite. Preservation is generally used to maintain the freshness of fish is by cooling, drying, and adding a substance (Hastuti, 2010). According to Oscar et al. (2009), several bacteria such as Salmonella sp., Shigella, Escherichia coli, Enterococci, and Clostridium often contaminate fish.

This paper intentionally presented a description of preserving milkfish meat using clove leaf oil (essential), especially those from Central Sulawesi, to increase knowledge about applying clove leaf oil for preservation.

\section{Methods}

The tools used in this study were a beaker, measuring cup, $\mathrm{pH}$ meter, thermometer, Erlenmeyer, a set of steam distillation tools, a set of simple distillation tools, aluminum foil, scissors, scales, digital balance, sample container, microflow (UV), autoclave, pycnometer, and vortex mixer.

The materials used in this study were clove leaves, distilled water, milkfish meat, $0.9 \% \mathrm{NaCl}$ solution (Merck), acetone, and alcohol solution (Onemed).

\section{Clove leaf oil preparation}

The first treatment was preparing clove leaf samples from Siwalempu Village, Sojol District. Then wash the clove leaves using clean water and let them stand at room temperature for 48 hours, and weigh $25 \mathrm{~kg}$. After that, the water was put into the steam distillation barrel to the specified limit, then the clove leaves were put into the distillation barrel, and the distillation was carried out for 8 hours.

\section{Clove leaf oil purification}

The first treatment was designing a simple distillation device, and then the oil was put into a simple distillation flask and distillates at a temperature of $105{ }^{\circ} \mathrm{C}$. Next, calculate the yield using the following formula (Vogel et al., 1996).

$$
\% \text { yield }=\frac{\text { weight of clove oil }}{\text { weight of clove leaf }} \times 100 \%
$$

\section{Characterization of clove leaf oil specific gravity}

The pycnometer was cleaned with acetone, dried, and then heated at $20{ }^{\circ} \mathrm{C}$. Then the pycnometer was weighed in an empty state; after that, the pycnometer was filled with distilled water and then weighed again. The pycnometer was emptied and cleaned, after which it was filled with clove leaf oil and then weighed. Calculate specific gravity with the following formula:

$$
\text { Relative density }=\frac{(\text { mass of pycometer }+ \text { mass of liquid })-(\text { mass of empty pycometer })}{\text { volume of liquid in pycometer }}
$$

\section{Addition of clove leaf oil to milkfish meat}

Cleaned milkfish was placed in 13 different containers. Clove leaf oil added containers 1, 2, 7, and 8 with a concentration of $8 \%$, containers 3,4 , 9 , and 10 with a concentration of $10 \%$, and containers $5,6,11$, and 12 with a concentration of $12 \%$ then covered with aluminum foil. Meanwhile, container 13 did not add clove leaf oil. In containers $1,2,3,4,5$, and 6 were allowed to stand for one day, containers $7,8,9,10,11$, and 12 were allowed to stand for three days, while container 13 is not left to rest.

\section{Observation parameters}

\section{Measurement of fish meat $p H$}

According to Suwetja (2007), pH determination can be done by taking the fish meat before and after it is preserved and then crushing it using a blender. Next step, 5 grams of fish meat in a beaker was added $10 \mathrm{~mL}$ of distilled water and homogenized it using a stirring rod. Then the $\mathrm{pH}$ of the fish was measured using a $\mathrm{pH}$ meter.

\section{Observation of the number of microbes}

According to Damongilala (2009), the total plate count (TPC) method is used. The first step was sterilizing petri dishes, Erlenmeyer, test tubes, distilled water, and agar medium utilizing an autoclave. Next, take the fish meat, preserved before and after being blended. After that, the blended fish meat is weighed as much as 10 grams, and $90 \mathrm{~mL}$ of distilled water was added. Then carry out a stratified dilution of the sample employing $10^{-1}$ dilution is obtained by inserting $1 \mathrm{~mL}$ of the sample into $9 \mathrm{~mL}$ of $0.9 \% \mathrm{NaCl}$ solution, $10^{-2}$ dilution is obtained from entering $1 \mathrm{~mL}$ of sampling from $10^{-1}$ dilution 
into $9 \mathrm{~mL}$ of $\mathrm{NaCl} 0.9 \%$ and so on up to a $10^{-5}$ dilution. After that, in the $10^{-4}$ and $10^{-5}$ dilution series, $100 \mu \mathrm{L}$ was taken, then sprinkled on each of the two surfaces of the NA media and spread evenly using a triangular rod, then incubated at room temperature for 24 hours. After 24 hours of incubation, observe the growing colony and count the number with the following formula (Fardiaz, 1993).

Colony $(\mathrm{CFU} / \mathrm{mL})=\sum$ colony $\times 1 / \mathrm{fp} \times$ $1 /$ disseminated inoculum

\section{Organoleptic test}

The organoleptic properties of fish meat were then evaluated before and after preservation (color, smell, texture, and taste). The level of color preference is determined by observing the color shift of the fish meat. The degree of choice for the smell is determined by smelling the fish meat. The sense of touch is used to measure the level of preference for texture, while the sense of taste is used to assess the amount of choice for flavor (Wijayanti \& Lukitasari, 2016).

\section{Results and Discussion}

\section{Clove leaf oil}

Clove leaf oil is an essential oil distilled by clove leaves that have dried (generally those that have fallen). The composition of the resulting oil varies depending on the state of the leaves and the way to stabilize them (Megawati et al., 2010).

Several methods can manufacture clove leaf oil, and one of the methods used in this research is steam distillation. First, the clove leaves are washed, which is the purpose of cleaning the clove leaves so that there are no impurities attached to the clove leaves, which can affect the oil content obtained, then dried at room temperature for 48 hours weighed as much as $25 \mathrm{~kg}$. Then the distillation process was carried out for 8 hours. This method is easy and safe for the environment because it does not use harmful organic solvents. Isolation by steam distillation produces clove oil with eugenol content.

Oil produced from isolation is generally impure, followed by simple distillation where the basis for separation is a significant difference in boiling point or with one of the volatile components. The component with the lower boiling point will evaporate first if the mixture is heated. So after the results of refining produce clove leaf oil as much as $1.2 \mathrm{~kg}$ and has a yield of $4.8 \%$. In the separation by distillation method, the compounds in the mixture with a lower boiling point will boil. The vapor then goes to the condenser, where it condenses into a liquid once more due to the cool temperature in the condenser (Ledgard, 2006).

The resulting clove oil is yellowish, has a distinctive aroma of clove leaf oil, evaporates quickly at room temperature, and has a specific gravity of $1.057 \mathrm{grams} / \mathrm{mL}$. According to Ardianto \& Tomi (2008), the distinctive aroma of clove oil is determined by the presence of eugenol content and the specific gravity of clove oil in the range of 1.030 grams $/ \mathrm{mL}-1.060$ grams $/ \mathrm{mL}$. Clove oil obtained from distillation is applied to milkfish.

Data on the results of $\mathrm{pH}$ measurements, the number of microbes, and organoleptic tests for milkfish meat are presented in Table 1.

Table 1. Data from $\mathrm{pH}$ measurements and the number of microbes of milkfish meat

\begin{tabular}{cccc}
\hline No & Treatment & $\mathrm{pH}$ & Total of microbes $(\mathrm{CFU} / \mathrm{mL})$ \\
\hline 1 & $\mathrm{~A}$ & 6.42 & $1.48 \times 10^{-7}$ \\
2 & $\mathrm{~B}$ & 6.61 & $2.46 \times 10^{-7}$ \\
3 & $\mathrm{C}$ & 6.64 & $2.03 \times 10^{-7}$ \\
4 & $\mathrm{D}$ & 6.67 & $1.83 \times 10^{-7}$ \\
5 & $\mathrm{E}$ & 7.20 & $2.98 \times 10^{-7}$ \\
6 & $\mathrm{~F}$ & 7.25 & $2.54 \times 10^{-7}$ \\
7 & $\mathrm{G}$ & 7.57 & $2.07 \times 10^{-7}$ \\
\hline
\end{tabular}

Description: A (Unresolved); B (1 day and a concentration of $8 \%)$; $\mathrm{C}(1$ day and $10 \%$ concentration); $\mathrm{D}$ (1 day and a concentration of 12 $\%)$; $\mathrm{E}$ (3 days and a concentration of $8 \%$ ); F (3 days and a concentration of $10 \%)$ and $\mathrm{G}(3$ days and a concentration of $12 \%)$.

\section{$p H$}

$\mathrm{pH}$ is the degree of acidity used to express the level of acidity or wetness of a solution (Astria et al., 2014). In this study, a $\mathrm{pH}$ meter was used to measure the $\mathrm{pH}$ of fish meat. The working principle of the $\mathrm{pH}$ meter is based on the electrochemical potential between the known solution in the glass electrode and the solution outside the unknown glass electrode. From the results of the research that has been done, the $\mathrm{pH}$ of milkfish ranges from 6.42 to 7.57. As shown in Table 1, the higher the concentration of clove leaf oil, the higher the $\mathrm{pH}$ obtained at each occupancy. Storage factors influence the high, and low $\mathrm{pH}$ of milkfish meat with a high $\mathrm{pH}$ is caused by alkaline compounds like ammonia, trimethylamine, and other volatile compounds. These compounds can also change the taste and smell of fish meat. (Hadiwiyoto, 1993). 
Increase the $\mathrm{pH}$ of fish meat because protein and fat are susceptible to chemical compounds. Clove leaf oil contains chemical compounds that can denature the protein in milkfish meat, and this results in milkfish with the addition of clove leaf oil having a higher $\mathrm{pH}$ than without the addition of clove leaf oil (Volt \& Wheeler, 1988). This is consistent with Aprianti (2011) assertion that the number of alkaline compounds present determines the severity of decay is determined by the number of alkaline compounds present; in this condition, the $\mathrm{pH}$ of the fish slowly increases, and the more alkaline compounds present, the higher the $\mathrm{pH}$; additionally, the level of bias results in an increase in the $\mathrm{pH}$ of fish meat. Meanwhile, Liviawaty \& Afrianto (2014) assert that the decrease in the hardness of fish meat results in increased activity of enzymes that spike fish meat. This enzyme comes from fish meat and is secreted by its environmental microbes. Overhaul by enzymes will produce alkaline compounds, which will cause the $\mathrm{pH}$ to increase.

\section{Total of microbes}

The method used in determining the number of microbes is the total plate count (TPC) method; the principle of the TPC or plate count method is to grow living microorganism cells on agar media so that the microorganisms will multiply and form colonies that can be seen directly and counted with the eye without using a microscope. This method is the most sensitive method used to determine microorganisms (Damongilala, 2009).

The media used were NA (nutrient agar) media. NA medium was a common medium used for water testing and dairy products. In addition, NA media is very suitable for samples where it is unknown what microorganisms are contained in the selection. In this method, the dilution technique is something that must be done. Before microorganisms are grown in the media, the sample is diluted using a physiological solution. The purpose of sample dilution is to reduce the amount of microbial content in the sample so that later the specific number of microorganisms can be observed and known so that an accurate calculation can be obtained-easy dilution in colony calculations (Fardiaz, 1993).

Table 1 shows that in each treatment, the number of bacteria in fish meat for a concentration of $12 \%$ was lower than the concentration of $10 \%$ and $8 \%$ for both one day and three days of indwelling. The use of clove leaf oil includes an antibacterial, antifungal, antioxidant, and traditionally as a flavoring agent and food preservative because clove leaf oil contains a chemical compound, namely eugenol. Eugenol compounds have lipophilic properties, resulting in adhesion to the bacterial cell membrane. The osmotic pressure increases, causing damage to the cell membrane and inhibiting bacterial respiration. Inhibition of the process of respiration in bacteria will disrupt transport in cells so that the bacteria will experience death. In the eugenol compound, phenol bonds will make the bacteria lysis and then die when attached to bacterial cells. This happens because the protein owned by fish meat experiences clumping so that the transpeptidase enzyme changes. Furthermore, there was a disturbance in forming the bacterial cell wall composed of peptidoglycan with polysaccharide and polypeptide groups. Cell walls that have been damaged and are not formed result in death.

\section{Organoleptic test}

The organoleptic test of a food ingredient can be observed in terms of color, aroma, texture, and taste-tested from 15 panelists.

The color of a food ingredient has an essential role in determining the quality and appeals to consumers so that consumers can give the impression of like it or not like it quickly (Winarno, 2004). Table 2 shows that the length of time and concentration of clove leaf oil is very influential in preserving milkfish meat. The quality of fresh meat can be seen from the color of the meat itself. The direct dye found in meat is myoglobin, a conjugated protein compound. The brightness of the meat color is determined by the thickness of the oxyhemoglobin layer on the surface of the meat. Suppose fresh meat is stored in a container that is not transparent to oxygen. In that case, the oxygen in the container will be depleted due to biochemical activity and microorganisms on the surface of the meat. So that over time, the color of the fish meat will change color until it is yellow or colorless (the fish meat is damaged) (Winarno, 2004).

The aroma of a food ingredient can affect the decrease in organoleptic value. It can be seen in Table 2, milkfish meat which has a low concentration has experienced a reduction in value for both one-day and three-day cultivation. The decrease in odor value was caused by the emergence of an additional strong odor, ammonia, and rotten on the milkfish meat, causing the panelists to dislike the fish meat in terms of aroma. The presence of microorganisms in fish also results in odor changes. This odor arises due to the emergence of ammonia $\left(\mathrm{NH}_{3}\right)$ in the degradation of protein and $\mathrm{H}_{2} \mathrm{~S}$ gas (Widiastuti, 2007).

The texture is a feature of a material as a result of a combination of several physical properties, which include size, shape, quantity, and elements of the formation of the material that can be felt by the sense of touch and taste, including the importance of mouth and sight (Midayanto \& Yuwono, 2014) Texture can affect value organoleptic a food by looking at the level of preference of the panelists. Tables 2 and 3 show that the lower the concentration and the longer it is stored, the organoleptic value decreases in terms of texture. The growth of fungi on the surface of the fish meat and bacterial activity on the inside of the fish meat accelerates the deterioration of the quality of the milkfish (Kaiang et al., 2016)). In addition, bacteria and enzymes cause degradation of the binding tissue, which causes a decrease in the texture value 
to become soft. Fish have a looser cell network arrangement so that microbes can easily use them as a growth medium. There is a change in glycogen to lactic acid in this phase due to blood circulation and reduced oxygen supplements. This change causes the $\mathrm{pH}$ of the fish's body to decrease, followed by a decrease in the amount of Adenosine Triphosphate (ATP) and the inability of muscle tissue to maintain its elasticity.

Table 2. Organoleptic test results data (color and smell)

\begin{tabular}{|c|c|c|c|c|c|c|c|c|c|}
\hline \multirow{2}{*}{ No } & \multirow{2}{*}{ Treatment } & \multicolumn{4}{|c|}{ Colour } & \multicolumn{4}{|c|}{ Smell } \\
\hline & & SS & $S$ & B & TS & SS & $S$ & $\mathrm{~B}$ & TS \\
\hline 1 & A & 9.0 & 6.0 & 0 & 0 & 0 & 9.0 & 4.0 & 2.0 \\
\hline 2 & B & 1.5 & 6.0 & 7.5 & 0 & 0 & 3.5 & 4.5 & 7.0 \\
\hline 3 & $\mathrm{C}$ & 3.5 & 7.5 & 4.0 & 0 & 0 & 5.0 & 4.5 & 5.5 \\
\hline 4 & D & 4.5 & 8.0 & 2.5 & 0 & 0 & 8.5 & 2.0 & 4.5 \\
\hline 5 & $\mathrm{E}$ & 0 & 0 & 3.5 & 11.5 & 0 & 0 & 0 & 15.0 \\
\hline 6 & $\mathrm{~F}$ & 0 & 1.5 & 3.5 & 10.0 & 0 & 0 & 1.5 & 13.5 \\
\hline 7 & G & 0.5 & 3.0 & 7.0 & 4.5 & 1.5 & 1.5 & 2.0 & 10.0 \\
\hline
\end{tabular}

Table 3. Organoleptic test results data (texture and taste)

\begin{tabular}{|c|c|c|c|c|c|c|c|c|c|}
\hline \multirow{2}{*}{ No } & \multirow{2}{*}{ Treatment } & \multicolumn{4}{|c|}{ Texture } & \multicolumn{4}{|c|}{ Taste } \\
\hline & & SS & $S$ & $\mathrm{~B}$ & TS & SS & $S$ & B & TS \\
\hline 1 & A & 4.0 & 9.0 & 2.0 & 0 & 5.0 & 8.0 & 2.0 & 0 \\
\hline 2 & B & 0.5 & 6.0 & 8.5 & 0 & 4.5 & 8.0 & 2.5 & 0 \\
\hline 3 & $\mathrm{C}$ & 1.0 & 5.5 & 8.5 & 0 & 3.0 & 7.5 & 4.5 & 0 \\
\hline 4 & $\mathrm{D}$ & 3.5 & 7.8 & 4.0 & 0 & 3.5 & 8.0 & 4.0 & 0.5 \\
\hline 5 & $\mathrm{E}$ & 0 & 0 & 1.5 & 13.5 & 0 & 0 & 0 & 15.0 \\
\hline 6 & $\mathrm{~F}$ & 0 & 0 & 2.0 & 13.0 & 0 & 0 & 0 & 15.0 \\
\hline 7 & G & 0 & 1.0 & 2.5 & 11.5 & 0 & 1.5 & 3.5 & 10.0 \\
\hline
\end{tabular}

Taste is the level of liking observed with the sense of taste. Based on the study results, Tables 2 and 3 show that fish that have undergone storage and have low concentrations have decreased their organoleptic taste in terms of taste. Fish indwelling for three days and a concentration of $8 \%$ in taste is very low. This is because the fish meat has been overgrown by bacteria and fungi so the panelists' preference for taste decreases. Clove leaf oil will have various effects on food, and it can significantly inhibit the growth of contaminating microbes. The sour taste is caused by environmental factors that support microbial growth during storage, such as moisture content, temperature, $\mathrm{O}_{2}$, so the development of microbes will damage the meat, and the level of consumers decreases.

The decline in the quality of the organoleptic fish meat (color, aroma, texture, and taste) is due to the enzymes in the fish's body that will remodel the body parts of the fish and cause changes in color smell, texture, and taste. Chemical activity is the oxidation of meat fat by oxygen. The oxygen in the air oxidizes the fatty meat of the fish and creates a rancid odor. Changes caused by bacteria are triggered by the damage to components in the fish's body by enzyme activity and chemical activity. Bacteria prefer this condition to trigger the growth of bacteria in fish meat. The quality deterioration process is very complex, interconnecting and working simultaneously.

According to Andries et al. (2004), clove extract has an antibacterial effect in inhibiting the growth of Streptococcus mutans bacteria in vitro. Meanwhile, Sukandar et al. (2010) stated that clove flower essential oil inhibits the growth of B. subtilis, B. cereus, E. coli P. aeruginosa, and S. aureus essential oils, clove flower essential oil is more effective against B. subtilis and B. cereus so that it has the potential to be antibacterial.

\section{Conclusions}

Based on the results obtained, it can be concluded that clove leaf oil is effective against preservation in terms of $\mathrm{pH}$, the number of microbes, and organoleptic tests. The higher the concentration of clove leaf oil, the greater the ability to preserve milkfish meat; it was proven that the 12 $\%$ concentration was superior to the $10 \%$ and $8 \%$ concentrations for both one day and three days of indwelling.

\section{Acknowledgment}

The author's gratitude goes to the Laboratory of Biotechnology Laboratory of the Faculty of Mathematics and Natural Sciences UNTAD and all those. They helped the author a lot in completing this research.

\section{References}

Andries, J. R., Gunawan, P. N., \& Supit, A. (2014). Uji efek anti bakteri ekstrak bunga cengkeh terhadap bakteri streptococcus muatans secara in vitro. e-GiGi: Jurnal Ilmiah Kedokteran Gigi, 2(2), $1-8$ 
Andayani, T., Hendrawan, Y., \& Yulianingsih, R. (2014). Minyak atsiri daun sirih merah (piper crocatum) sebagai pengawet alami pada ikan teri (stolephorus indicus). Jurnal Bioproses Komoditas Tropis, 2(2), 123-130.

Aprianti, D. (2011). Aktivitas antibakteri ekstrak biji picung (pagium edule reinw) dan pengaruhnya terhadap stabilitas fisiko kimia, mikrobiologi dan sensosi ikan kembung (rastrelliger neglectus). Unpublished Thesis (S1). Jakarta: Universitas Negeri Syarif Hidayatullah.

Ardianto., \& Tomi. (2008). Pengaruh ekstrak bunga cengkeh (syzygium aromaticum L.) terhadap mortalitas larva aedes aegypti L. Skripsi Tidak Diterbitkan. Surakarta: Universitas Sebelas Maret.

Astria, F., Subito, M., \& Nugraha, D. W. (2014). Rancang bagun alat ukur $\mathrm{pH}$ dan suhu berbasis short message service (SMS) gateway. Jurnal Jurnal Mektrik, 1(1), 47-55.

Damongilala, L. J. (2009). Kadar air dan total bakteri pada ikan roa (hemirhampus sp) asap dengan metode pencucian bahan baku berbeda. Jurnal Ilmiah Sains, 9(2), 190-198.

Fardiaz, S. (1993). Analisis mikrobiologi pangan. Jakarta: Raja Grapindo Persada.

Gusmawati., Laapo, A., \& Howare, D. (2014). Analisis kelayakan finansial usahatani cengkeh di desa Bou Kecamatan Sojol Kabupaten Donggala Provinsi Sulawesi Tengah. Agrotekbis: e-Journal Ilmu Pertanian, 2(3), 325-331.

Hadi, S. (2012). Pengambilan minyak atsiri bunga cengkeh (clove oil) menggunakan pelarut nheksana dan benzena. Jurnal Bahan Alam Terbarukan, 1(2), 25-30.

Hadiwiyoto, S. (1993). Teknologi pengolahan hasil perikanan. Yogyakarta: Liberty.

Hastuti S. (2010). Analisis kualitatif dan kuantitatif formaldehid pada ikan asin di Madura. Agrointek: Jurnal Teknologi Industri Pertanian, 4(2), 132-137.

Kaiang, D. B., Montolalu, L. A. D. Y., \& Montolalu, R. I. (2016). Kajian mutu ikan tongkol (Euthynnus Affinis) asap utuh yang dikemas vakum dan non vakum selama 2 hari penyimpanan pada suhu kamar. Jurnal Media Teknologi Hasil Perikanan, 4(2), 75-84.

Kataren, S. (1990). Kinetika reaksi biokimia. Bogor: Institut Pertanian Bogor.

Ledgard, J. B. (2006). A laboratory history of chemical warfare agents, $2^{\text {nd }}$ edition. United States.

Liviawaty, E., \& Afrianto, E. (2014). Penentuan waktu rigor mortis ikan nila merah (oreochromis niloticus) berdasarkan pola perubahan derajat keasaman. Jurnal Akuatika Indonesia, 5(1), 4044.
Megawati, R. F., Da'i, M., \& Munawaroh, R. (2010). Analisis mutu minyak atsiri bunga cengkeh (syzygium aromaticum (L.) meer. \& perry) dari Maluku, Sumatra, Sulawesi, dan Jawa dengan metode metabolomic berbasis GC-MS. Pharmacon: Pharmaceutical Journal of Indonesia, 11(2), 57-61.

Midayanto, D. N., \& Yuwono, S. S. (2014). Penentuan atribut mutu tekstur tahu untuk direkomendasikan sebagai syarat tambah dalam standar nasional Indonesia (in Press 2014). Jurnal Pangan dan Agroindustri, 2(4), 259-267.

Nurdjannah, N. (2004). Diversifikasi penggunaan cengkeh. Perspektif: Review Penelitian Tanaman Industri, 3(2), 61-70.

Oscar, G., Gómez-Duarte., Bai, J., \& Newell, E. (2009). Detection of escherichia coli, salmonella sp., shigella sp., yersinia enterolitica, vibrio chlerae, and camphylobacter sp. enteropathogens by 3 reaction multiplex polymerase chain. Diagnostic Microbiology and Infectious Disease, 63(1), 1-9.

Sharma, S.K., V.K. Srivastava \& Jasra, R.V. (2006). Selective double bond isomerization of allyl phenyl ethers catalyzed by ruthenium metal complexes. Journal of Molecular Catalysis A: Chemical, 245, 200-209.

Sukandar, D., Radiastuti, N., \& Khoeriyah. (2010). Karakterisasi senyawa aktif anti bakteri minyak atsiri bunga cengkeh (syzygium aromaticum). Jurnal Kimia Terapan Indonesia, 12(1), 1-7.

Suwetja, I. K. (2007). Biokimia hasil perikanan jilid III. Manado: Universitas Sam Ratulangi Manado.

Towaha, J. (2012). Manfaat eugenol cengkeh dalam berbagai industri di Indonesia. Perspektif: Review Penelitian Tanaman Industri, 11(2), 7990.

Vogel, A. I., Tatchell, A. R., Furnis, B. S., Hannaford, A. J., \& Smith, P. W. G. (1996). Vogel's textbook of practical organic chemistry, (5th Edition). Amerika Serikat: Prentice Hall.

Volt, W. A. \& Wheeler, M. F. (1988). Mikrobiologi dasar edisi kimia jilid 1. Jakarta: Penerbit Erlangga.

Widiastuti, L. (2008). Analisis mutu ikan tuna selama lepas tangkap pada perbedaan preparasi dan waktu penyimpanan. Bogor: Institut Pertanian Bogor.

Wijayanti, N. S., \& Lukitasari, M. (2016). Analisis kandungan formalin dan uji organoleptik ikan asin yang beredar di pasar besar Madiun. Florea: Jurnal Biologi dan Pembelajarannya, 3(1), 5964.

Winarno, F. G. (2004). Kimia pangan dan gizi. Jakarta: PT Gramedia Pustaka Utama. 